\title{
Macular corneal dystrophy
}

INSERM

\section{Source}

INSERM. (1999). Orphanet: an online rare disease and orphan drug data base. Macular corneal dystrophy. ORPHA:98969

Macular corneal dystrophy (MCD) is a rare, severe form of stromal corneal dystrophy (see this term) characterized by bilateral ill-defined cloudy regions within a hazy stroma, and eventually severe visual impairment. 